\title{
1,3-Alternate Calix[4]arene Bifuntional Fluorescent Receptor Containing Urea and Crown Ether Moieties
}

\author{
Byung Ju Ryu, Nam Joong Jeon, and Kye Chun Nam*
}

\author{
Department of Chemistry, Chonnam National University, Gwangju 500-757, Korea. *E-mail: kcnam@chonnam.ac.kr \\ Received August 28, 2010, Accepted September 13, 2010
}

Key Words: Calix[4]arene, Excimer, Monomer, Bifunctional receptor

Calix[4]arenes are important building blocks in supramolecular chemistry. ${ }^{1,2}$ The calixarene framework provides a unique possibility to organize several binding sites in an array complementary to a potential guest. A variety of calixarene-based receptors for cations, ${ }^{3}$ anions ${ }^{4}$ and neutral molecules ${ }^{5}$ have been synthesized in the past decade. Though anion recognition ${ }^{6}$ appears to be a relatively new area of research, both positively charged and neutral receptors for anionic species have been prepared in the last few years. $^{7}$

As fluorogenic units, pyrenes are one of the most useful because of their relatively efficient excimer formation and emission. ${ }^{8}$ Since the intensity ratio of the excimer to the monomer emission $\left(I_{\mathrm{E}} / I_{\mathrm{M}}\right)$ is sensitive to conformational changes of the pyrene-appended receptors, changes in $I_{\mathrm{E}} / I_{\mathrm{M}}$ upon metal ion complexation can be an informative parameter in various sensing systems. ${ }^{9,10}$ The simultaneous binding of cationic and anionic guest species by ditopic receptors is a rapidly developing new field for ion pair recognition of environment and biological importance. By taking advantage of calixarene framework, a few neutral bifunctional receptors ${ }^{11-13}$ were developed and showed the simultaneous complexation properties of hydrophilic anions and cations in organic media. Those receptors are, however, only focused on the cone conformers of calix[4]arene. It has been known ${ }^{14}$ that 1,3-alternate conformation of calix[4]arene could provide the two excellent binding sites for guest molecules when the proper functionalization could be achieved. We have previously reported 'bifunctional calix[4]arene receptors' containing two urea groups and crown ether moieties at the calix[4]arene fixed in the 1,3-alternate conformation. It was shown the simultaneous binding properties of cation and anion guests with enhanced binding affinity of halide anions in the presence of potassium cation. ${ }^{15}$

Here we report a new bifunctional receptor 1 based on 1,3alternate conformer of calix[4]arene, which contains urea linking pyrene fluorophores instead of phenylurea and crown ether moieties at the opposite side of lower rim of calix[4]arene fixed in the 1,3-alternate conformation. Also, we studied binding affinity of various anions in the present of potassium ion.

\section{Results and Discussion}

Reaction of $2^{16}$ with 1-pyrenemethylisocyanate in dioxane gave the bifunctional receptor $\mathbf{1}$ in $70 \%$ yield as shown in Scheme 1 .

The ${ }^{1} \mathrm{H}$ NMR spectrum of 1 shows the characteristics ${ }^{17}$ of 1,3 -alternate conformation such as a narrow range chemical
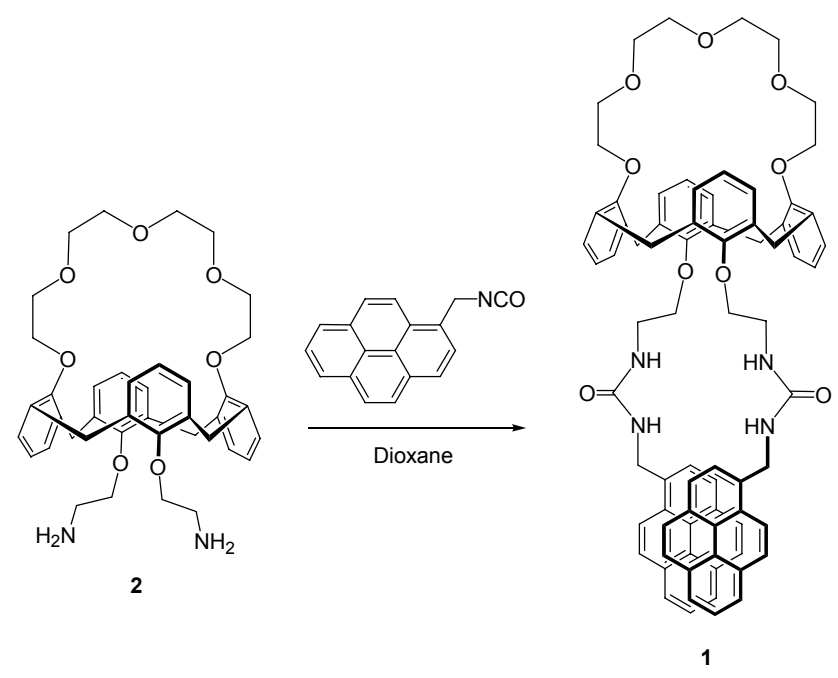

Scheme 1. Synthetic routes to fluorescent chemosensor 1

shift of aromatic protons at $\delta 6.7-7.3$ and a singlet like peak at $\delta 3.74$ for bridge methylene protons. A large singlet containing two very small outer peaks were observed instead of a pair of doublets. Four urea N-H protons appear as a broad singlet at $\delta$ 5.50 and 5.08 as expected. The ${ }^{13} \mathrm{C}$ NMR spectra of 1 also confirmed the 1,3-alternate conformation, which showed one peak at $\delta 38.0$ for the bridge methylene carbons as an indication of all anti oriented phenolic rings. We probed the anion binding abilities of 1 based on fluorescence changes of their DMSO solutions produced by addition of salts of the anions tetrabutylammonium $\mathrm{CH}_{3} \mathrm{COO}^{-}, \mathrm{H}_{2} \mathrm{PO}_{4}^{-}, \mathrm{C}_{6} \mathrm{H}_{5} \mathrm{COO}^{-}$. In the free ligand, the two pyrene units in $\mathbf{1}$ exhibit weak monomer $\left(\lambda_{\mathrm{em}}=375 \mathrm{~nm}\right)$ and strong excimer $\left(\lambda_{\mathrm{em}}=475 \mathrm{~nm}\right)$ bands, Which could be attributed to two facing pyrene units in an intramolecular $\pi$ - $\pi$ stacked arrangement. An anion titration of 1 show an almost no changes in the fluorescence emission intensities of the monomer and excimer bands.

But, upon addition of $\mathrm{K}^{+}$ion which is suitable for calix[4] crown-5 of 1 , the excimer emission of pyrene unit decreases and monomer emission of pyrene unit increases because the $\mathrm{K}^{+}$ion complexation induces the conformational change of the two pyrene ureas to quenching the $\pi-\pi$ interaction in Figure 2 .

It is northworthy that the H-bonding based anions complexation are enhanced not only by an allosteriacal conformational change induced by $\mathrm{K}^{+}$ion complexation in the crown-5 loop but also by more efficient ion-pairing electrostatic interaction 


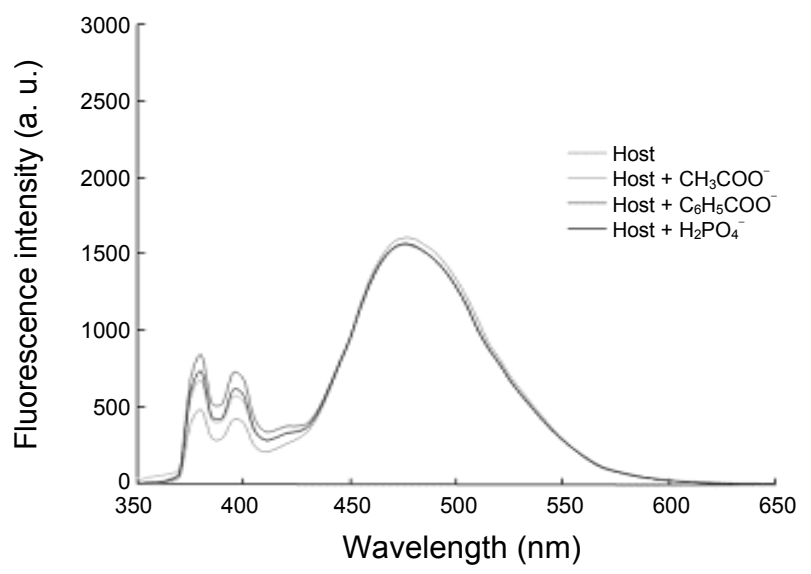

Figure 1. Emmision spectra of $\mathbf{1}(1.0 \mu \mathrm{M})$ upon the addition of anions to 1,000 eq in DMSO. (The excitation wavelength is $340 \mathrm{~nm}$ ).

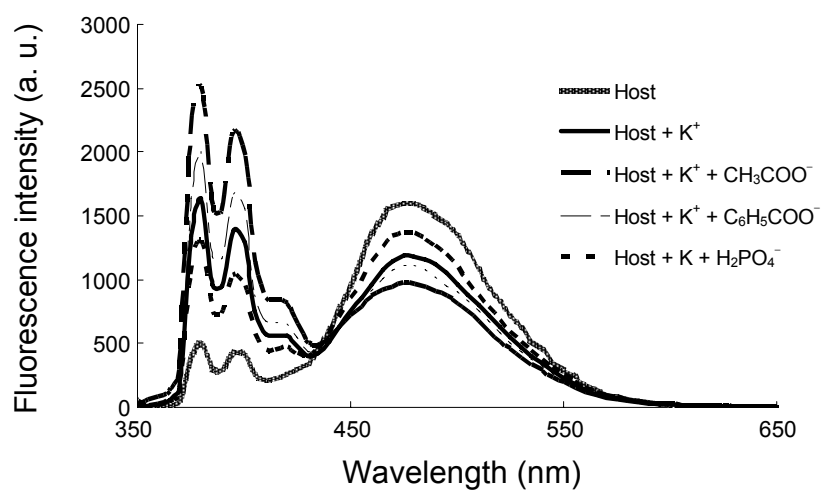

Figure 2. Emmision spectra of $\mathbf{1} \cdot \mathrm{K}^{+}(1.0 \mu \mathrm{M})$ upon the addition of anions to 1,000 eq in the presence of $\mathrm{K}^{+}(10.0 \mathrm{eq})$ in DMSO. (The excitation wavelength is $340 \mathrm{~nm}$ ).

between $\mathrm{K}^{+}$and anions. The cation and anion binding properties of 1 were examined by ${ }^{1} \mathrm{H}$ NMR titration experiments in DMSO- $d_{6}$. The addition of 1 equivalent of $\mathrm{KClO}_{4}$ caused a down field shift of aromatic and methylene protons, which was observed previously ${ }^{16}$ in similar crown ether derivatives of calix[4] arene. Further addition of $\mathrm{KClO}_{4}$ does not make a change, suggesting that receptor- $\mathrm{K}^{+}$forms a 1:1 stoichiometry complexes and complexes are formed in solution with potassium ion at the crown ether group. Substantial down field shift of urea NH signal was observed when tetrabutylammonium acetate, benzoate, dihydrogene phosphate salts were added, indicating that anion binding is taking place at the urea vicinity. Stability constants were calculated from the titration results using EQNMR ${ }^{18}$ for complexation with fluoride, acetate, benzoate and dihydrogen phosphate in order to investigate binding enhancement in the presence of potassium ion. An enhancement in the strength of actate and benzoate ions binding is observed when potassium ion is bound simultaneously as shown in Table 1.

Acetate binding strength increase more than three folds and benzoate binding eight folds in the presence of potassium ion. This positive cooperative binding of the acetate and benzoate in the presence of potassium could be attributed to electrostatic effect of the complexed metal cation. The structural change of ligand upon binding potassium ion was not clear based on ${ }^{1} \mathrm{H}$
Table 1. Stability constants $\left(K_{a}\right)$ of receptor $\mathbf{1}$ in DMSO

\begin{tabular}{ccccc}
\hline \multirow{2}{*}{ Metal $^{a}$} & \multicolumn{4}{c}{$\mathrm{K}^{b} / \mathrm{dm}^{3} \mathrm{~mol}^{-1}$} \\
\cline { 2 - 5 } & $\mathrm{CH}_{3} \mathrm{COO}^{-}$ & $\mathrm{C}_{6} \mathrm{H}_{5} \mathrm{COO}^{-}$ & $\mathrm{H}_{2} \mathrm{PO}_{4}^{-}$ & $\mathrm{F}^{-}$ \\
\hline None & 104 & 51 & 94 & 77 \\
$\mathrm{~K}^{+}$ & 298 & 430 & $-^{b}$ & $-b$ \\
\hline
\end{tabular}

${ }^{a}$ Titration carried out in the presence of 1 equivalent of metal cation salt, potassium perchlorate. ${ }^{b}$ Due to the broadness, binding constants can not be determined. ${ }^{c}$ Errors estimated to be $<10 \%$.

NMR spectrum, indicating that electrostatic effect could be the major force for enhancing anion binding. In conclusion, 1,3alternate calix[4]arene pyrene urea derivative 1 have been synthesized by the $\mathbf{2}$ and their corresponding 1-pyrenemethylisocyanate. Bifunctional receptor 1 can bind potassium cation and acetate and benzoate anions simultaneously with positive cooperativity.

\section{Experimental}

25,27-Bis[( $N$-pyrenemethylureido)ethyloxy]calix[4]arenecrown-5, (1). To a $0.2 \mathrm{~g}(0.3 \mathrm{mmol})$ of $2 \mathrm{in} 20 \mathrm{~mL}$ of 1,4-dioxane, $0.1 \mathrm{~mL}$ of pyrenylisocyanate was added and the mixture was stirred for $3 \mathrm{~h}$ under the nitrogen atmosphere. After removing the solvent, the residue was triturated with $\mathrm{MeOH}$, filtered and dried to give $0.19 \mathrm{~g}(61 \%)$ of $1 .{ }^{1} \mathrm{H} \mathrm{NMR}\left(\mathrm{CDCl}_{3}\right) \delta$ 7.76-7.33 (m, 18H, PyH), 7.10 and $6.87(\mathrm{~d}, 4 \mathrm{H}, \mathrm{ArH}, J=6.8 \mathrm{~Hz}), 6.73$ and $6.53(\mathrm{t}, 4 \mathrm{H}, \mathrm{ArH}, J=6.2 \mathrm{~Hz}), 5.51$ and 5.14 (broad s, $4 \mathrm{H}$, -NH), 3.95 (s, 4H, - $\left.\mathrm{CH}_{2} \mathrm{Py}\right), 3.71$ (s, 8H, $\left.\mathrm{ArCH}_{2} \mathrm{Ar}\right), 3.58$ (m, 4H, $\left.-\mathrm{OCH}_{2-}\right), 3.52\left(\mathrm{~m}, 4 \mathrm{H},-\mathrm{OCH}_{2-}\right), 3.49$ (t, 4H, $-\mathrm{OCH}_{2-}-J=6.9$ $\mathrm{Hz}$ ), 3.13 (t, 4H, - $\mathrm{NCH}_{2}-, J=6.9 \mathrm{~Hz}$ ), 2.77 (br s, 4H, $-\mathrm{OCH}_{2}-$ ), 2.68 (br s, $\left.4 \mathrm{H},-\mathrm{OCH}_{2}-\right) ;{ }^{13} \mathrm{C} \mathrm{NMR}\left(\mathrm{CDCl}_{3}\right) \delta 156.4,156.1$, 155.8, 139.1, 134.9, 134.1, 129.8, 129.5, 129.1, 123.1, 122.9, and 120.1 (Ar), 73.1, 70.9, 70.0, 69.5, and $68.3\left(-\mathrm{OCH}_{2}-\right), 40.7$ $\left(-\mathrm{CH}_{2} \mathrm{~N}-\right), 38.0\left(\mathrm{ArCH}_{2} \mathrm{Ar}\right)$.

Acknowledgments. NMR spectra were taken at the Korea Basic Science Institute, Kwangju, Korea. This work was supported by the Korea Science and Engineering Foundation (KOSEF) grant funded by the Korea government (MOST) (No. R01-2007000-20245-0).

\section{References}

1. Gutsche, C. D. Calixarenes, Monographs in Supramolecular Chemistry; Stoddart, J. F., Ed.; The Royal Society of Chemistry: London, 1989; Vol. 1.

2. Descalzo, A. B.; Rurack, K.; Weisshoff, H, Martinez-Manez, R.; Marcos, M. D.; Amoros, P.; Hoffmann, K.; Soto, J. J. Am. Chem. Soc. 2005, 127, 184.

3. Cobben, P. L. H. M.; Egberink, R. J. M.; Bomer, J. G.; Bergveld, P.; Verboon, W.; Reinhoudt, D. N. J. Am. Chem. Soc. 1992, 114, 10573.

4. Thiagarajan, V.; Ramamurthy, P.; Thirumalai, D.; Ramakrishnan, V. T. Org. Lett. 2005, 7, 657.

5. (a) Gutsche, C. D.; See, K. A. J. Org. Chem. 1992, 57, 4527. (b) wan Loon, J. D.; Janssen, R. G.; verboom, W.; Reinhoudt, D. N. Tetrahedron Lett. 1992, 33, 5125.

6. Benjamin, S.; Nameer, A.; Dermot, D. J. Am. Chem. Soc. 2006, 
$128,8607$.

7. Quinlan, E.; Matthews, S. E.; Gunnlaugsson, T. J. Org. Chem. 2007, 72, 7497.

8. Kim, S. K.; Lee, S. H.; Lee, J. Y.; Lee, J. Y.; Bartsch, R. A.; Kim, J. S. J. Am. Chem. Soc. 2004, 126, 16499.

9. Jung, H. S.; Park, M.; Han, D. Y.; Kim, E.; Lee, C.; Ham, S.; Kim, J. S. Org. Lett. 2009, 11, 3378.

10. Xie, J.; Menand, M.; Maisonneeuve, S.; Metivier, R. J. Org. Chem. 2007, 72, 5980 .

11. Scheerder, J.; van Duynhoven, J. P. M.; Engberson, J. F. J.; Reinhoudt, D. N. Angew. Chem. Int. Ed. Eng. 1996, 35, 1090.
12. Pelizzi, N.; Casanati, A.; Friggeri, A.; Ungaro, R. J. Chem. Soc. Perkin Trans. 1998, 2, 1307.

13. Beer, P. D.; Cooper, J. B. Chem. Commun. 1998, 1, 129.

14. Rudkevich, D. M.; Mercer-Chalmers, J. D.; W. Verboom, W.; Ungaro, R.; de Jong, F.; Reinhoudt, D. N. J. Am. Chem. Soc. 1995, $117,6124$.

15. Kang, S. O.; Nam, K. C. Bull. Korean Chem. Soc. 2002, 23, 640.

16. Kang, S. O.; Nam, K. C. Bull. Korean Chem. Soc. 2000, $21,461$.

17. Igbal, M.; Mangiafico, T.; Gutsche, C. D. Tetrahehdron 1987, 43, 4917.

18. Hynes, M. J. J. Chem. Soc. Dalton Trans. 1993, 2, 311. 